\title{
久陥を有する柱梁溶接接合部の変形能力に関子る実験的研究 EXPERIMENTAL STUDY ON DEFORMATION CAPACITY OF WELDED BEAM-TO-COLUMN CONNECTION WITH WELD DEFECTS
}

\author{
中込忠男*1, 服部和徳*2, 市川祐一*3, 的場 耕*4, 岩田 衛*5 \\ Tadao NAKAGOMI, Kazunori HATTORI, Yuichi ICHIKAWA, \\ Kou MATOBA and Mamoru IWATA
}

\begin{abstract}
The welding defect of the welding connection in steel structure causes the brittle fracture. Especially because the beam-to-column connection is a part by which the biggest stress is received, this defect gives fatal damage to the steel structure frame. In this research, the full scale experiment in the beam-to-column connection was done, and fracture behavior and the deformation capacity by which the welding defect was made a starting point were examined. The influence which the welding defect produces on the deformation capacity of the beam-to-column connection is large and decreases the possession performance. Moreover, it is possible to become an effective index to evaluate the deformation capacity that the crack characteristic size is shown by the penetration crack by WES -2805 .
\end{abstract}

Keywords: beam-to-column welded connection, welding defect, crack size, fracture behavior, deformation capacity 柱梁溶接接合部, 溶接欠陷, 亀裂寸法, 破壊性状, 変形能力

\section{1. $F$}

䤡部材における脆性破壊現象は破壊起点となる亀裂の存在が重要 な破棲因子となり得るが、この亀裂には部材の塑性変形に伴い発生 する延性龟裂以外にも、溶接施工により生じる欠陥が考えられる。

そのため、溶接欠陥が継手性能に及ぼす影響を把握した上で対策 を講じることが耐震設計上重要となる。

また、龬構造物において溶接接合は随所に用いられるがその部位 によって要求性能は異なる。特に柱梁接合部は地輑時に最も大きな 応力を受ける部位であるため、接合部ディテール、溶接欠陥等の影 響を受け、架構全体の变形能力が著しく低下することが懸念される。 溶接施工において生じる溶接欠陥としては、スラグ巻き込みやブ ローホールといった溶着金属中の欠宿の他、溶接始終端初層付近に おける溶け込み不良や融合不良が想定される。超音波挆鹪検査にお いても欠陥指示長さの最小值が設定され、板厚 $\mathrm{t} / 4$ 以下の溶接欠陷 は合否判定の対象外となっている。1) 3)

藤本、泉は欠陥を有する $\mathrm{T}$ 継手突合せ溶接部の単純引張試験及び 定ひずみ振幅低サイクル疲労試験を行い、溶接継手の中央部におけ る欠陥よりも両端部における欠宿の影響が大きいことを示している 4) 6)。溶接施工においてェンドタブに代替タブを用いた場合、形状
の不連続は無くなり銅製タブと梁フランジとのスリット部のような 応力集中部は低減するが、溶接始終端部のダイアフラム側熱影警部 側に溶接欠陥が生じやすく、溶接始終端部に欠陥が存在した場合、 この部分が起点となる可能性がある。しかし、溶接欠宿の位置及び 形状が柱梁溶接接合部の変形能力に与える影響について検討した研 究は少ない7。

本研究は溶接欠宿を有する柱梁溶接接合部の実大実験を行い、溶 接欠陥を起点とした破断による柱梁溶接接合部の破罗性状を把握し、 溶接欠陥の形状及び寸法と柱梁溶接接合部の変形能力との関係つい て検討を行うことを目的とする。

\section{2. 実験概要}

2.1 実験パラメータ

実験パラメータは梁フランジ板幅方向 ld と梁フランジ板厚方向 hd の溶接欠陥寸法であり、超音波探賃検查においてエコー高さによ る領域は予測できないが、板幅方向の欠宿寸法は日本建築学会「鋼構 造建築溶接部の超音波探賃検查基浑・同解説」3に基づく欠宿評価長 さの境界值を基準とし、大きく分けて 3 つの欠宿長さ目標值を設定 した。板厚方向の久宿寸法はほぼ 1 パス分に相当する $5 \mathrm{~mm}$ を基準 としたが、比較のために梁フランジ板厚方向に溶接欠陥が貫通して
${ }^{* 1}$ 信州大学工学部社会開発工学科 教授.工博

*2 信州大学工学部社会開発工学科 大学院生

*3 傍州大学工学部社会開発工学科 助手·博士 (工学)

*4 信州大学工学系研究科 大学院生・修士 (工学)

*5 神奈川大学工学部建築学科 教授. 工博
Prof., Dept. of Architecture and Civil Engineering, Faculty of Engineering, Shinshu Univ., Dr. Eng.

Graduate Student, Dept. of Architecture and Civil Engineering, Faculty of Engineering, Shinshu Univ.

Research Assoc., Dept. of Architecture and Civil Engineering, Faculty of Engineering, Shinshu Univ., Dr. Eng.

Graduate Student, Dept. of Architecture and Civil Engineering, Faculty of Engineering, Shinshu Univ., M. Eng.

Prof., Dept. of Architecture, Faculty of Engineering, Kanagawa Univ., Dr. Eng. 
いる試験体を 2 体製作した。武験体一筧を表 1 に示す。

前述のように本研究において扱う溶接欠陥は溶け込み不良や融合 不良といった未溶着欠陥とし、溶接欠陥位置は溶接始終端部のダイ アフラム側初層付近とした。溶接欠陌製作位置を図 1 に示寸。溶接 欠陥は、初層の溶接時にアークの极らいを意図的に外すことで作製 した溶接欠陥（以下、久陥 $\mathbf{a}$ と称す。）とあらかじめ鋼板を挿入する ことによってメタルタッチ部分を設けた溶接欠陥（以下、欠陥 $\mathrm{b}$ と 称す。）の 2 種類である。溶接欠陥は武験体 1 体につき上下フランジ の両幅端部、計 4 筬所に設けた。

\section{2 武稳体}

試験体形状及び接合部詳細を図 2 に示す。試験体は柱梁接合部を モデル化した $\mathrm{T}$ 字形部分架構であり、全試験体とも梁部材に压延 $\mathrm{H}$

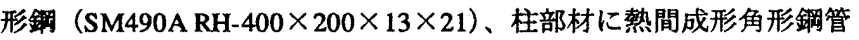
（STKR ロ $-400 \times 400 \times 25 ）$ を用いて、通しダイアフラム（SN490B PL-450 $\times 450 \times 28 ）$ 形式で溶接接合して製作した。接合方法は工場溶 接接合とし、接合ディテールはノンスカラップ工法を用いた。また、 梁端部において破境を生じさせるために試験体に用いた柱部材及び パネルソーンは梁部材に比べて十分な強度を持たせた。

梁フランジの溶接は溶接ワイヤーYGW-11（1.2 $\phi)$ を用いて、 $\mathrm{CO}_{2}$ ガスシールドアーク半自動溶接により下向き溶接とした。入熱は全 試路体とも30kJ 以下であるが、パス間温度管理は $250^{\circ} \mathrm{C}$ 管理のもの と連続管理のものと 2 種類である。溶接条件を表 2 に示す。また、 エンドタブは代替タブとし、L 形フラックスタブを用いた。L形フ ラックスと取り付け位固図を図 3 に示す。欠陥 b は梁フランジ端部 に㨂入し、ダイアフラム側端部と溶接金属とが溶着しないよう施工 した。裹当て金には $1 / 2$ カット、フィレット密着型を用い、断続す み肉溶接により組み立てた。

\section{3 秦材試験結果}

本研究においては開先内のダイアフラム側に溶接欠陥が存在し、 かつ、エンドタブに代替タブを用いておりダイアフラム母材熱影響 部も破壊起点となることが想定される。そのため、梁フランジ母材 と熱影镘部及び溶着金属（DEPO）の他、ダイアフラム母材と熱影 謷部についてシャルピー衝撃試験を行った。試験片は試験体と同様 な溶接条件で製作された溶接部から採取し、梁フランジ母材熱影響 部の試験片は梁フランジ表層から、ダイアフラム母材熱影響部の試 験片は溶接欠陷位置を想定し初層部分からそれぞれ採取した。ノッ チは全てサイドノッチとした。試験片形状及び採取位置を図 4 に示 す。梁材の機械的性質を表 3、化学成分を表 4 に、シャルピ一衝撃 試験（JIS Z 2202 試銩片）結果を表 5 及び図 5 に示す。遷移温度評 価は最小自乗近似を用いて (1)、（2）式により曲線の回㷌を行った。

表 5 及び図 5 のシャルピー衝慗試験結果から、梁フランジ母材及 びダイアフラム母材ともに、溶接条件に関わらず熱影響部の方が靭 性が高いことがわかる。

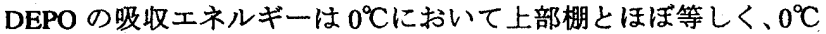
吸収エネルギーは梁フランジ熱影響部、DEPO、ダイアフラム熱影 帮部の順に高くなっている。

また、溶接条件の影響については入熱とパス間温度管理の両因子 が関わってくるが、本研究の場合はパス間温度のみ異なり、梁フラ ンジ母材熱影警部に関しては $0^{\circ} \mathrm{C}$ 吸収エネルギー、脆性破面率に若 干の相迺が見られる程度となっている。一方、ダイアフラム母材熱
表 1 栻験体一臨

\begin{tabular}{|c|c|c|c|c|c|}
\hline \multirow{2}{*}{ 試䬭体 } & \multirow{2}{*}{ 欠鲬韾作方法 } & \multicolumn{3}{|c|}{ 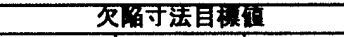 } & \multirow{2}{*}{ 溶接条件 } \\
\hline & & ld(mm) & hd(mm) & ${ }_{s}^{\alpha}$ & \\
\hline $\mathrm{FaS1}$ & \multirow{5}{*}{ 欠䐄a ${ }^{* 1}$} & 7 & \multirow{7}{*}{5} & 0.02 & \multirow{3}{*}{$30 \mathrm{~kJ} / 250^{\circ} \mathrm{C}$} \\
\hline FaM 1 & & \multirow{3}{*}{15} & & \multirow{3}{*}{0.04} & \\
\hline FaM2 & & & & & \\
\hline FaM3 & & & & & \multirow{8}{*}{$30 \mathrm{~kJ} /$ 連続 } \\
\hline $\mathrm{FaLI}$ & & 40 & & 0.10 & \\
\hline FbM 1 & \multirow{6}{*}{ 欠陷 $\mathrm{b}^{* 2}$} & 15 & & 0.04 & \\
\hline $\mathrm{FbM2}$ & & 13 & & 0.04 & \\
\hline Fbm 1 & & 5 & 21 & 0.05 & \\
\hline FbL1 & & 40 & 5 & 0.10 & \\
\hline Fbll & & 10 & 21 & 0.10 & \\
\hline FbLL1 & & 40 & 10 & 0.20 & \\
\hline F01 & 哭L & $\sim$ & 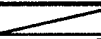 & $\infty$ & $30 \mathrm{~kJ} / 250^{\circ} \mathrm{C}$ \\
\hline F0G1 & 補修 & 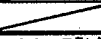 & 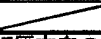 & $\longrightarrow$ & 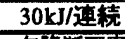 \\
\hline
\end{tabular}

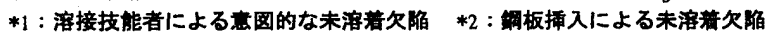

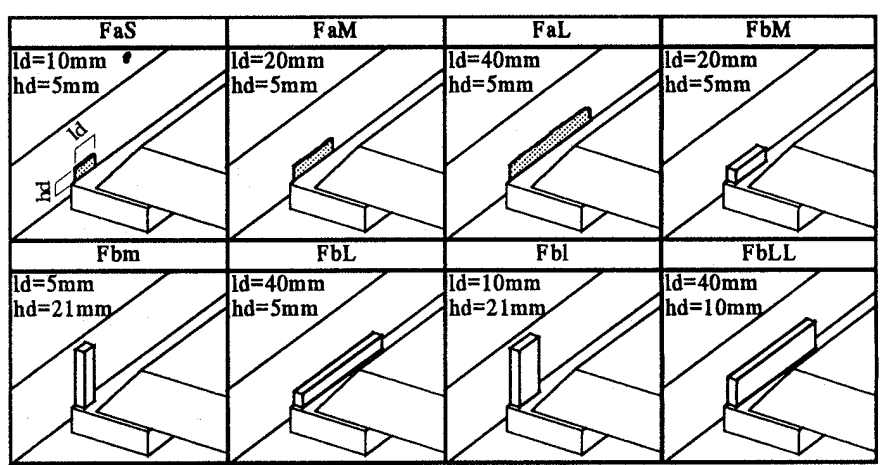

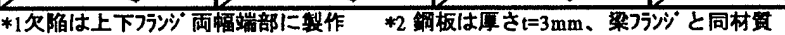

图 1 溶接欠楩製作位置
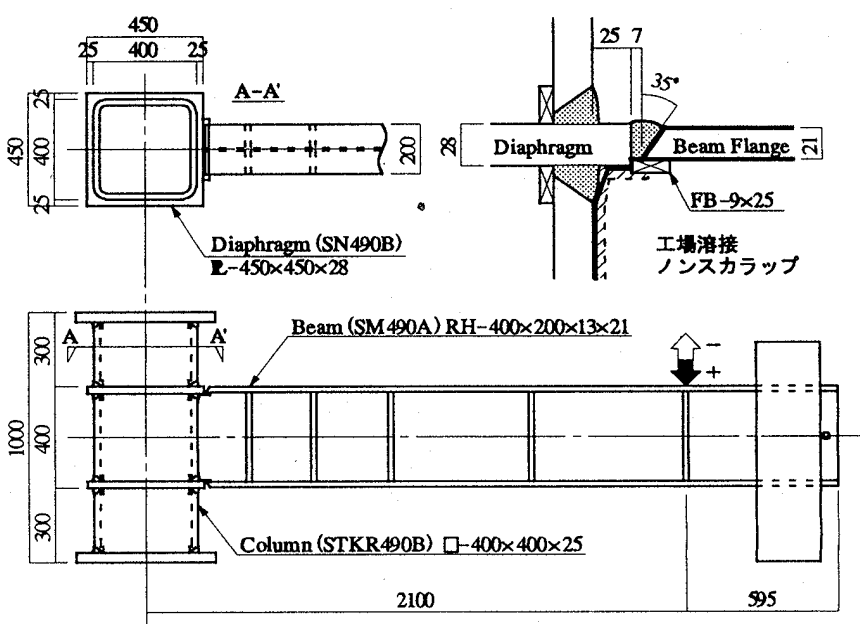

图 2 試験体形状及び接合部詳細 (Unit：mm)
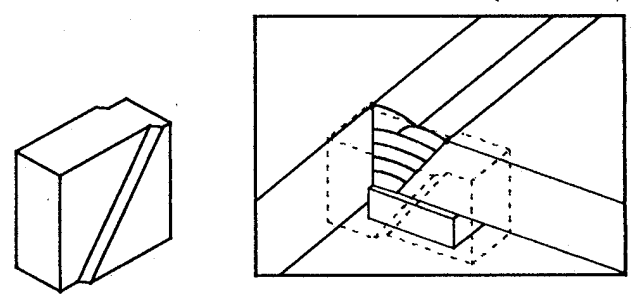

図 3 フラックスタブ形状及ひ取り付け位置

影響部に関してはほとんど差はみられない。

本研究ではダイアフラム側初層付近に位置する溶接欠陥を想定 しているため、ダイアフラム熱影響部の試験片は初層から採取した。 パス間温度は開先から $10 \mathrm{~mm}$ 離れた梁フランジ中央部において計測 し、3パス目まではパス間温度が目標の温度に達しず連続溶接と同 
表 2 湲接条件

\begin{tabular}{|c|c|c|c|c|c|c|}
\hline & $\pi \lambda$ & $7-53$ (4 (sec) & 霆流(A) & 蛋压(V) & 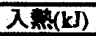 & 积酒四 \\
\hline \multirow{6}{*}{$\begin{array}{c}30 \mathrm{~kJ} \\
250^{\circ} \mathrm{C} \\
\text { YGW-11 }\end{array}$} & 1 & \begin{tabular}{|l}
37.1 \\
\end{tabular} & \multirow{6}{*}{$\begin{array}{c}300 \sim 420 \\
\text { Ave334 }\end{array}$} & \multirow{6}{*}{$\begin{array}{l}34 \sim 40 \\
\text { Ave35 }\end{array}$} & 25.4 & \\
\hline & 2 & 38.6 & & & 27.0 & \\
\hline & 3 & 44.2 & & & 31.3 & \\
\hline & 4 & 46.1 & & & 32.0 & \\
\hline & 5 & 36.1 & & & 27.0 & \\
\hline & 6 & 37.0 & & & 28.0 & 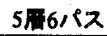 \\
\hline \multirow{7}{*}{$\begin{array}{c}30 \mathrm{~kJ} \\
\text { 這殸 } \\
\text { YGW-11 }\end{array}$} & 1 & 35.8 & \multirow{7}{*}{$\begin{array}{c}290 \sim 370 \\
\text { Ave } 338\end{array}$} & \multirow{7}{*}{$\begin{array}{c}35 \sim 40 \\
\text { Ave } 37\end{array}$} & 22.3 & \\
\hline & 2 & 36.1 & & & 22.4 & \\
\hline & 3 & 46.5 & & & 28.9 & \\
\hline & 4 & 38.5 & & & 24.0 & \\
\hline & 5 & 42.1 & & & 25.9 & \\
\hline & 6 & 37.3 & & & 23.2 & \\
\hline & 7 & 36.6 & & & 22.9 & 5) \\
\hline
\end{tabular}

様の条件となったため、勒性に差は見られなかったと考えられる。 したがって、此端部（最終層）を起点とした破壊については個別視 する必要があるが、意図した溶接欠陥（初層付近）を起点とし破壊 に至る場合はパス間温度の違いを無視し、同様に扱うこととした。

$$
\begin{aligned}
& v E(T)=\frac{v E_{\text {sheff }}}{\exp \left[-\alpha\left(T-v T_{E}\right)\right]+1} \\
& C_{r}(T)=\frac{100}{\exp [\beta(T-v T s)]+1}
\end{aligned}
$$

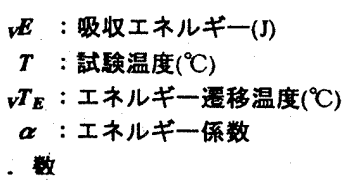

$C_{r} ：$ 䀠性破面事(\%)

、正部棚吸収エネルギー(J)

$v T_{S}:$ 破面圐移温度 $\left({ }^{\circ} \mathrm{C}\right)$

$\boldsymbol{\beta}:$ 破面係

\section{4 苩倚方法}

試釦体は図 6 に示すように柱上下端をピン支持とし、梁端部（図 中の斜線部分）とパネルソーンをドライアイスと氷等を用いて、 $0^{\circ} \mathrm{C}$ で 1 時間以上冷却した後に変位制御により静的載荷(載荷速度 $0.1 \mathrm{~mm} / \mathrm{sec}$ )を行った。

载荷振幅は梁部材の全塑性モーメント $\mathrm{M}_{\mathrm{P}}$ に対応する梁端回転角

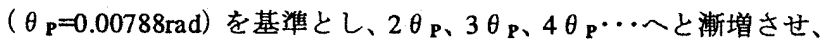
各振幅で 2 サイクルずつとした。梁の載荷履歷を図 7 に示す。また 図 6 中の(2)、(3)、(4)の変位計から得られるパネルのせん断変形量を 考慮して、(1)のレーザー変位計によって得られる梁端変形角からパ ネルの変形角 $\theta_{\mathrm{J}}$ を修正したものを梁端有効回転角 $\theta_{\mathrm{m}}$ とした。 $\theta_{\mathrm{m}}$ の模式図を図 8 に示す。

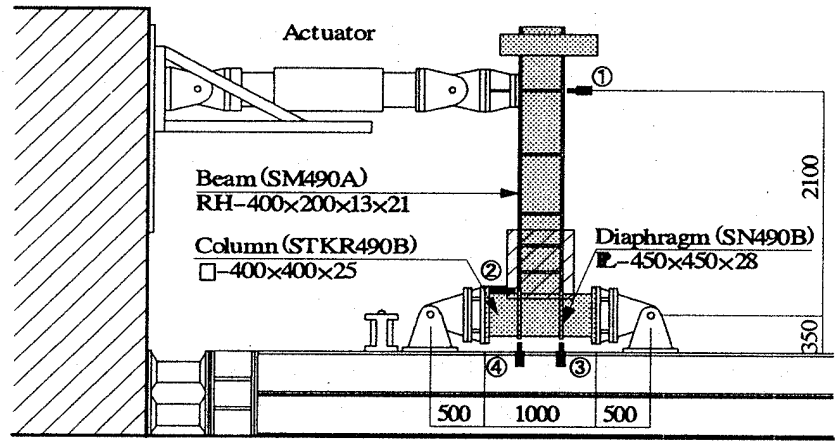

图 6 戴荷状況 (Unit：mm)

表 3 梁部材の力学的特性(ミルシート值)

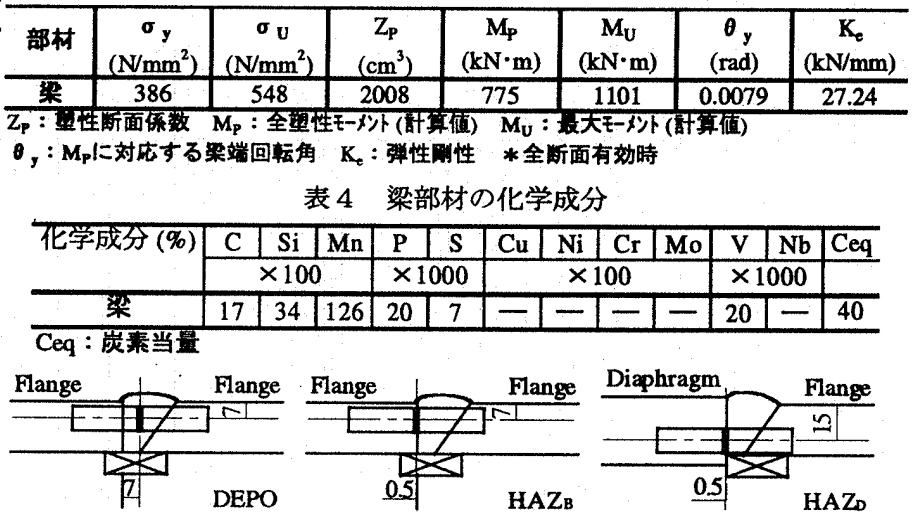

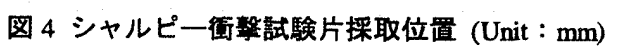

\begin{tabular}{|c|c|c|c|c|c|c|}
\hline \multicolumn{2}{|r|}{ 試験片 } & $\mathrm{v}_{\mathrm{E}}\left({ }^{\circ} \mathrm{C}\right)$ & ${ }_{v} E_{0}(J)$ & $\mathrm{v}_{\mathrm{gher}}(\mathrm{J})$ & ${ } \mathrm{T}_{\mathrm{S}}\left({ }^{\circ} \mathrm{C}\right)$ & $C_{r}(\%)$ \\
\hline \multirow{3}{*}{ フランジ } & 母材 & 11 & 69 & 191 & 30 & 84 \\
\hline & HAZ-ボンド $\left(250^{\circ} \mathrm{C}\right.$ & -34 & 223 & 243 & -23 & 13 \\
\hline & HAZ-ボンド(連噩) & -22 & 194 & 253 & -12 & 33. \\
\hline \multirow{3}{*}{ タイアフラム } & 母材 & 12 & 89 & 217 & 18 & 73 \\
\hline & $\mathrm{HAZ}$ ボンド $\left(250^{\circ} \mathrm{C}\right.$ & -8 & 136 & 238 & -7 & 40 \\
\hline & HAZ-ボンド(連続) & 0 & 134 & 267 & -8 & 38 \\
\hline \multirow{2}{*}{ 楁接金属 } & $250^{\circ} \mathrm{C}$ & -31 & 204 & 208 & -23 & 11 \\
\hline & 連続 & -40 & 197 & 207 & -17 & 26 . \\
\hline
\end{tabular}
表 5 シャルピー衝試試験果

$\mathrm{v}_{\mathrm{E}}$ : I机

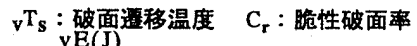
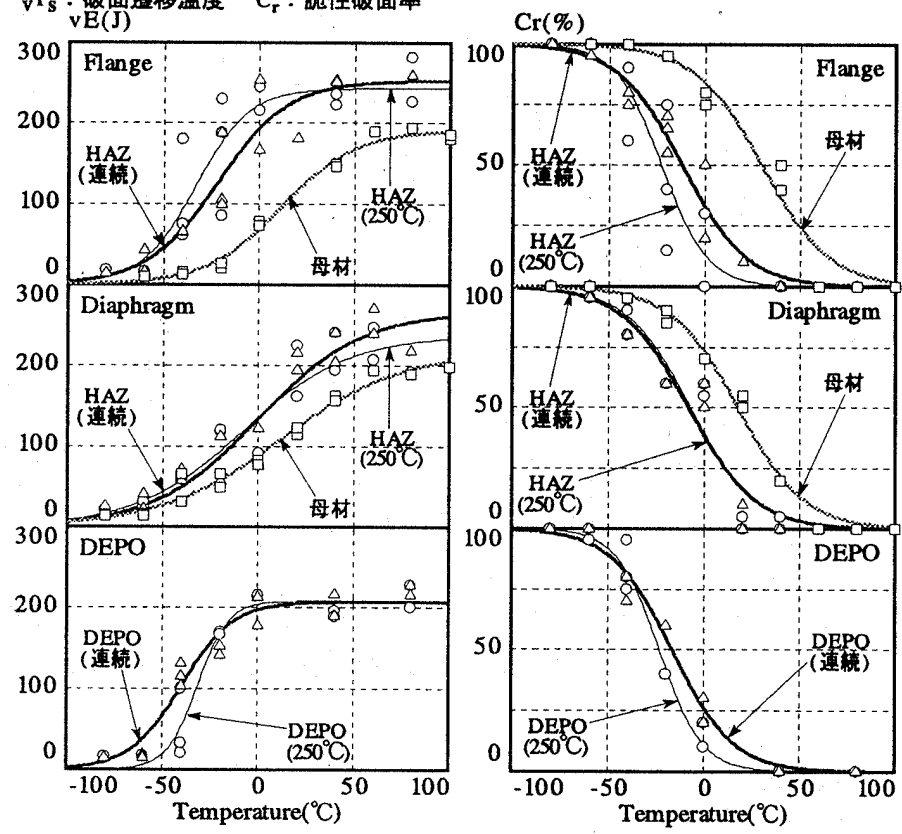

図 5 シャルピー衝擊試験結果

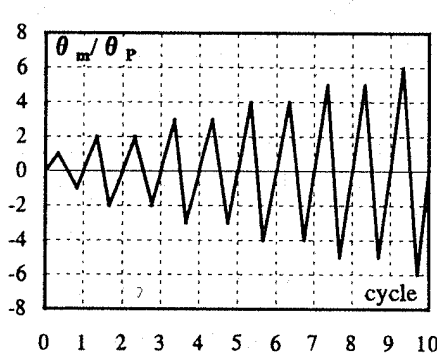

图 7 载荷屡歴

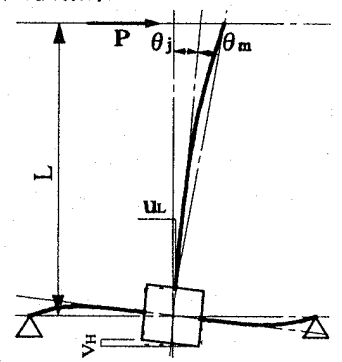

图 8 梁端回転角 $\theta$ m 
表 6 实験結果一卧

\begin{tabular}{|c|c|c|c|c|c|c|c|c|c|c|c|c|c|c|c|c|c|c|}
\hline \multirow{2}{*}{ 試輅体 } & \multirow{2}{*}{$\begin{array}{l}\text { 整局 } \\
\text { 時期 }\end{array}$} & \multicolumn{2}{|c|}{$M_{m(\max )}(k N \cdot m)$} & \multicolumn{2}{|c|}{$\theta=(\max )(\mathrm{rad})$} & \multicolumn{2}{|c|}{$\theta_{\mathrm{s}}(\mathrm{rad})$} & \multicolumn{2}{|c|}{$\mathrm{W}_{\mathrm{S}}(\mathbf{k N} \cdot \mathrm{m})$} & \multirow{2}{*}{$\begin{array}{c}\mathrm{W} \\
(\mathrm{kN} \cdot \mathrm{m})\end{array}$} & \multicolumn{2}{|c|}{$\alpha$} & \multicolumn{2}{|c|}{$\boldsymbol{\eta}_{\mathrm{s}}$} & \multicolumn{2}{|c|}{$E \eta_{S}$} & & \multirow{2}{*}{$\begin{array}{l}\text { 破震 } \\
\text { 形式 }\end{array}$} \\
\hline & & + & & + & & + & & + & & & + & - & + & - & + & - & & \\
\hline fasi & $7(2)$ & 188 & 1256 & 60488 & 0.0485 & 0.07962 & 600708 & 66 & 60. & 122, & 1149 & X162. & 1010 & 890. & 1088 & 937. & 236. & $\mathrm{H}_{1} \mathrm{z}_{2}$ \\
\hline FaMI & 1710 & 111 & 1195 & 0.0419 & 0.0420 & 0.0649 & 000608 & 51 & 48. & 545 & 1\% & (1) & 832 & T\%? & 8 & 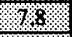 & 178 & TIAY, \\
\hline $1 \mathrm{M}$ & $5 s(2)$ & 1053 & 11143 & 0.0353 & 000351 & 0.0479 & 0.0481 & 32 & 34 & 271 & 1136 & 1617 & 60 & 610 & 828 & 5 & 90 & $\mathrm{Ftaz}_{\mathrm{B}}$ \\
\hline 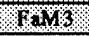 & 17212 & 11313 & $1 / 243$ & 0.0683 & 000489 & 0.0766 & 007724 & 63 & 61. & 695 & 146. & (1000 & \% 21 & 药設 & $10 \%$ & 10,0 & 227. & $\mathrm{H}_{\mathrm{H}} \mathrm{Z}_{\mathrm{z}}$ \\
\hline Sull & US & 1043 & 1080 & 0.0833 & $00028 \%$ & 00048. & 000391 & 29 & 24. & 204 & 13.3. & 1,39 & $5 \%$ & 50 & 48 & 400 & 67. & 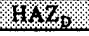 \\
\hline FbMI & $-8(1)$ & 1170 & -1264 & 0.0553 & -0.0488 & 0.0889 & -0.0715 & 77 & 61 & 904 & 1.51 & -1.63 & 11.3 & 9.1 & 12.7 & 9.9 & 296 & $\mathrm{HAZ}_{\mathrm{B}}$ \\
\hline $\mathrm{FbM} 2$ & $+7(2)$ & 1137 & -1243 & 0.0477 & -0.0492 & 0.0743 & -0.0748 & 61 & 64 & 673 & 1.47 & -1.60 & 9.4 & 9.5 & 10.1 & 10.5 & 220 & $\mathrm{HAZ}_{\mathrm{B}}$ \\
\hline Fbm I & $-6(1)$ & 1096 & -1150 & 0.0421 & -0.0352 & 0.0591 & -0.0517 & 44 & 38 & 401 & 1.41 & -1.48 & 7.5 & 6.6 & 7.3 & 6.1 & 131 & etc \\
\hline Tbit: & $7(2)$ & 145 & 1222 & 000486 & $0.0487 \%$ & 00963. & 000705 & 63. & 59. & 157. & 148 & 1158 & 9.97. & 89 & 1033 & 96 & 248 & $1 \mathrm{NL}_{3}$ \\
\hline r66i: & 411 & 1004 & 1071 & 6.0283 & 0.0280 & 0.0362 & 0.0379 & 21 & 23 & 22 & 1.29 & 1138 & 46. & 68 & 34. & 38 & $40 \%$ & $\mathrm{HATz}$ \\
\hline Fbigrt: & $4(2)$ & 1025 & 1078 & 0.8286 & 0.0283 & 000385 & 010380 & 232 & 23 & 175 & 1.32 & 1339 & 49 & 48 & 88 & 38 & S7. & $18 z_{1}$ \\
\hline F01 & $-7(2)$ & 1132 & -1223 & 0.0488 & -0.0488 & 0.0794 & -0.0712 & 66 & 59 & 734 & 1.46 & -1.58 & 10.1 & 9.0 & 10.8 & 9.7 & 240 & $\mathrm{HAZ}_{\mathrm{B}}$ \\
\hline FOG & $-7(2)$ & 1145 & -1223 & 0.0488 & -0.0486 & 0.0783 & -0.0696 & 66 & 58 & 744 & 1.48 & -1.58 & 9.9 & 8.8 & 10.7 & 9.5 & 243 & etc \\
\hline
\end{tabular}
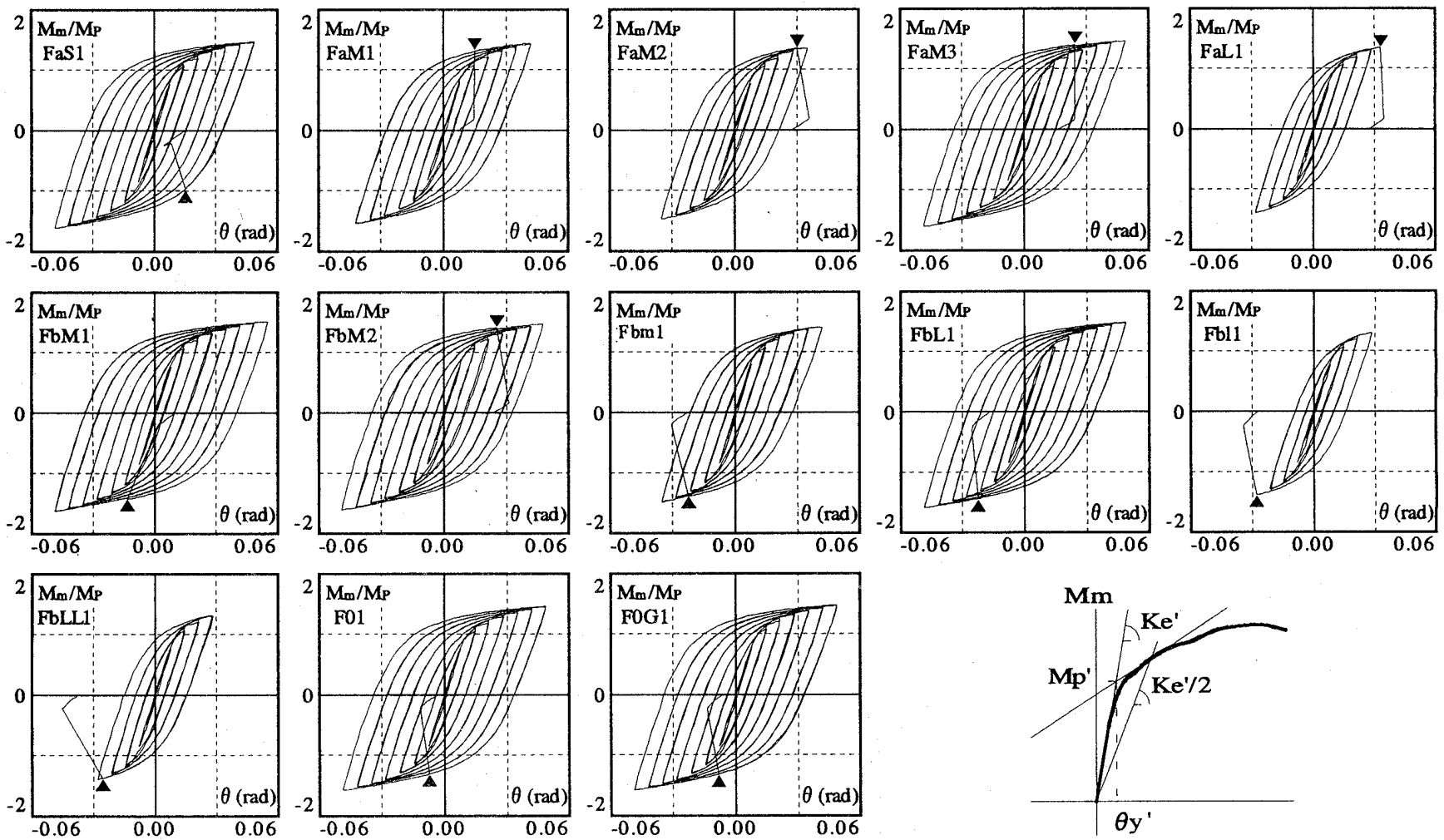

図 9 無次元化梁端曲げモーメントー梁端回転角関係

図 10 General-Yield 法による算出方法

\section{3.央験㷬果}

\section{1 実験結果概要}

実験結果一覧を表 6 に示し、無次元化梁端曲げモーメント $\mathrm{M}_{\mathbf{m}} / \mathrm{M}_{\mathbf{P}}$ 一梁端回転角 $\theta_{\mathrm{m}}$ 関係を図 8 に示す。General-Yield 法による $\mathrm{M}_{\mathrm{P}}{ }^{\prime}$ の算 出法を図 10 に、skelton 曲線及び $W_{\mathbf{P}} 、 W_{\mathbf{S}}$ の模式図を図 11 に示す。 によって求めた梁部材の全塑性モーメント実験值 $\mathrm{M}_{\mathbf{P}}$ 'は試験体間で 大きな差は無く、計算值よりも平均で 6\%上回る程度であったため、 無次元化する際に用いる弾性限界吸収エネルギーW の有無に関わらず、梁全断面有効とした場合の計算值 $\mathrm{M}_{\mathrm{P}} 、 \boldsymbol{\theta}_{\mathrm{P}}$ を用

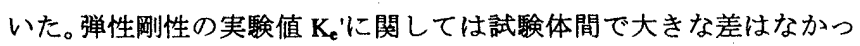
たものの、計算值よりも実験值の平均が $24 \%$ 下回ったため、skelton 曲線における塑性吸収エネルギー $W_{s}$ 及び無次元化履歴吸収エネル ギー ${ }_{\mathrm{E}} \eta_{\mathrm{S}}$ の算出に用いる弾性剖性には試験体それぞれの実験値を用

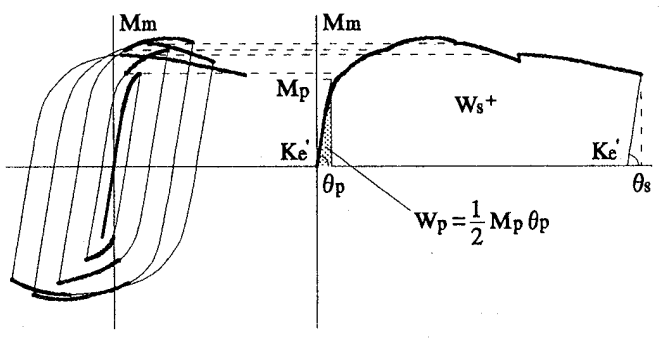

図 11 skelton曲線及び W $、 W_{S}$

いた。図 9 をみるとどの試験体も、安定した履歴を描いていること がわかる。破壊性状については次項で述べるが、どの試験体も座屈 は生じず、延性刍裂も顕著な進展がみられず急激に耐力が低下した。 なお、図 9 中のムは梁フランジの破断時を示している。

\section{2 破面银察結果}




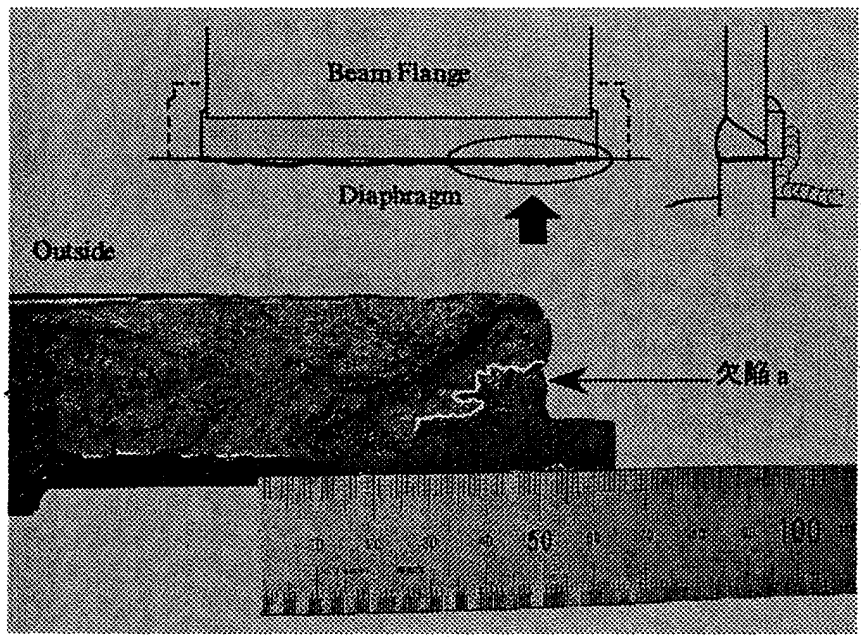

FaM1

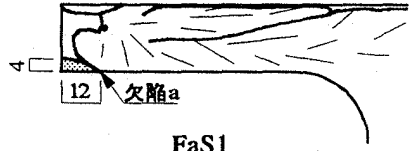

FaS1

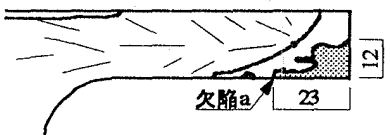

FaM1

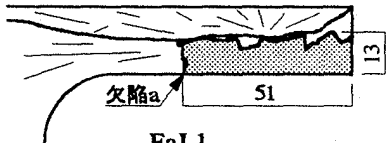

FaLl

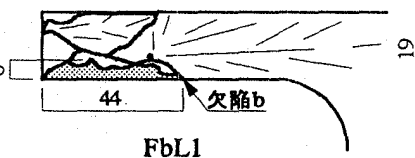

FbL1

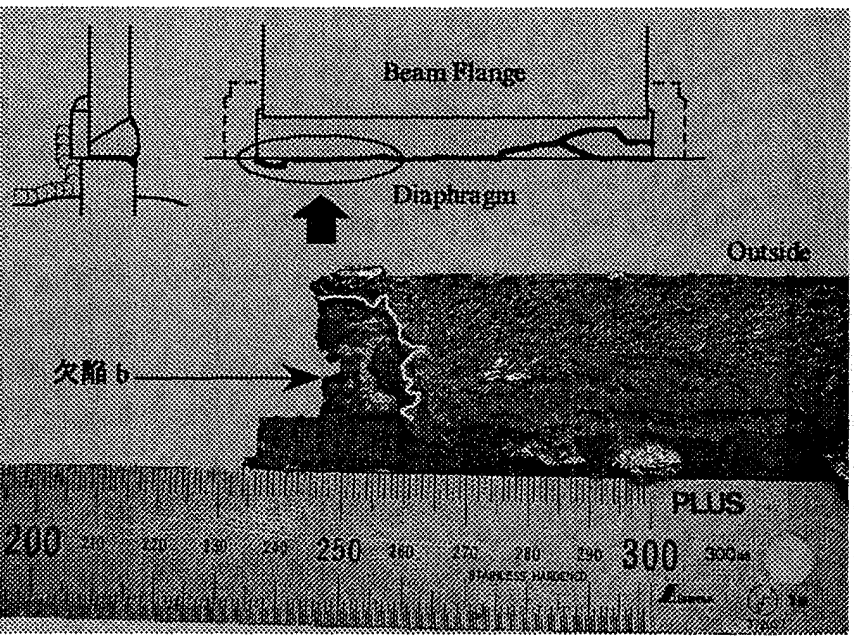

Fbll

*網掛け部は、本実験で作製した溶接欠陌

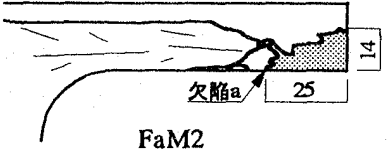

FaM2

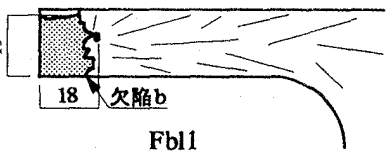

Fbl1

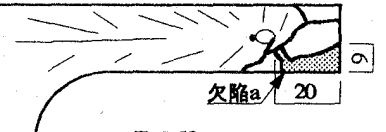

FaM3

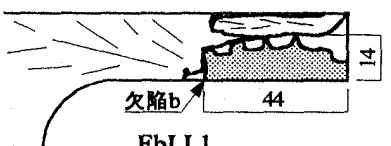

FbLL1

图 13 破面観察結果

試験体の梁フランジ側破断面の目視による破面観察を行い、溶接 久陷寸法を計測した。久䧄を起点として破断に至った試験体の破面 短察結果を図 $12 、 13$ に示す。梁フランジの破断状況は以下の 3 種類 であった。

$\mathrm{HAZ}_{\mathbf{B}}$ : 梁フランジ侧溶接止端部から発生した延性龟裂が進展し、 久陥 $\mathrm{a}$ または欠陥 $\mathrm{b}$ に達し、延性龟裂の近傍において脆性刍裂に転 化し破断に至った。脆性亀裂は梁フランジ母材に伝播した試験体が 多くみられた。ただし破断面には現れていないものの、ダイアフラ ム側初層部分に久宿の存在が確瑟された試験体もみられた。

$\mathbf{H A Z}_{\mathbf{p}}$ : ダイアフラム側初層部分に設けた溶接欠陷から延性龟裂 が発生・成長した後、脆性象裂に転化しダイアフラム母材もしくは 溶着金属中を伝播した。

etc：FOG1 と Fbml は他の試験体と同様に溶接止端部に延性龟裂 が発生・進展したが、本実酮で意図した以外の欠陥である溶接金属 中の銀点を起点として脆性笔した。

\section{4.考䋈}

\section{1 弨音波探侮検查}

通常、鋼構造溶接部の欠宿に対しては非破塄検査として超音波探 伤検查(UT 検査)が行なわれる。本実験の試験体も日本建築学会「鋼 構造建筑溶接部の超音波探倁検查基準・同解説」に従い UT 検査を行 った。表 7 VT 険査結果及び破面観察結果による溶接欠陥寸法を 示す。UT 検査の合否は久陷評価長さの境界值とエコー高さによる 領域を用いて判定する。本実験においては梁フランジ厚が $\mathrm{t}=21 \mathrm{~mm}$
であるためエコー高さによる領域が 川の場合、久陷評価長さの境界 值 $\mathrm{L}=31.5 \mathrm{~mm}(3 \cdot t / 2)$ 、領域がW及びIVの場合は久宿評価長さの境界值 $M L=21 \mathrm{~mm}(\mathrm{t})$ が、領域が Vの場合は欠陥評価長さの境界值 $\mathrm{M}=15.75 \mathrm{~mm}(3 \cdot t / 4)$ がそれぞれの合否ラインとなる。

久陷以外を起点として破断した試験体については言及できない が、UT 検查による欠陥指示長さと破面観察による久宿寸法実測值 は、UT 検査結果の方が平均で $10 \mathrm{~mm}$ 程小さい值となっている。ま た、UT 検查結果が不合格となった試験体は 4 体で、全て溶接欠陥 を起点として破断した。

\section{2 龟裂特性寸法}

構造物において一般に問題となる溶接欠陥は 3 次元の板厚非貫通 (表面もしくは埋没)刍裂が多いが、日本溶接協会WES-2805による 亀裂特性寸法は応力搪大係数 $\mathrm{K}$ 值の等価則を用いて板厚非貫通刍裂 を 2 次元の板厚貫通亀裂に置き換えることにより様々な溶接欠陥を 同等に評価することを試みている8。

本研究では亀裂特性寸法を用いて溶接欠陥と梁部材の変形能力 との関連性について考察を行った。亀裂特性寸法の算出に用いる溶 接欠陥寸法には、計画値と多少前後するが破面観察結果によって得 られた実測値を用いることとした。溶接欠陥を標準化する際は欠陥 (亀裂先端)と板材の自由表面との距離(開口もしくは貫通している かどうか)が問題となる。本実験の溶接欠宿位置は図 2 に示すように 実験計画において意図した初層部分に存在しており、塞当て金の組 立溶接が断続組立溶接であることから、試跧体の溶接欠陥を半椅円 
表 7 欠宿寸法一覧

貫通龟裂 (表面亀裂)として扱い龟裂特性寸法を求めることとした。 図 14 に刍裂特性寸法の標準化方法と算出方法を示す。

\section{3 裂特性寸法と交形能力の関保}

図 15 に亀裂特性寸法とスケルトン曲線における無次元化履歷吸 収エネルギーの関係を示す。図 13 において両者の関係は、大きく2 つの部分に分けられる。亀裂特性寸法がある值（こでは $A=13 \mathrm{~mm}$ 前後）以下の武験体群は、 $A=0$ つまり溶接欠陥が無いF01 とほぼ同 等の $\mathrm{E} \eta \mathrm{S}$ の值を示していることから、A=13 mm 以下の試験体群で は溶接欠陷を有することによる変形能力への影著な影響は認められ ない。しかし、 $A=13 \mathrm{~mm}$ 以上の試験体群は溶接欠陥無しの F01 と比 較すると、龟裂特性寸法の值が大きくなるにつれて $\mathrm{E} \eta \mathrm{S}$ の值が小さ くなり、変形能力が低下する負の相関関係が琶められる。

シャルピー衝慗試験から得られたパス間温度管理の違いによる 初層部分の勒性値に差違はないため、この相関について、初層付近 の欠陥を起点として破断した試験体はパス間温度管理の違いによる 影謷はほぼ無視できる。板厚方向に欠陥寸法が大きい試験体 Fbl1 は、 溶接欠俩が無いF01 と比較すると変形能力の低下が著しくなってい る。

比較的龟裂特性寸法が近い值の FaM'3 と FbL1 や FaL1 と FbLL1 を比较すると多少のバラッキはあるものの、ほぼ同等の変形能力を 示していることから、溶接欠陷の製作方法の違いが変形能力に及ぼ す影翠は認められない。しかし、亀裂特性寸法と変形能力との間に ある負の相関は欠宿 $\mathrm{a}(\boldsymbol{O})$ 、欠陥 $\mathrm{b}(\bigcirc)$ のどちらの場合にも認められ る。

また、前述のUT 検查における合否ラインに対して板厚方向の久 宿寸法をおよそ 1 パス分 $(4 \mathrm{~mm} \sim 6 \mathrm{~mm})$ と仮定した場合、UT 検査合否 珜定の境界值は刍裂特性寸法が $A=7 \sim 11 \mathrm{~mm}$ に相当し、この值は図 15 において変形能力の低下が影著となり始める值 $(A=13 \mathrm{~mm})$ よりも 若干低くなっている。従ってUT 検查の合否判定基準自体は安全側 の評価を与えていると言える。しかし、FbL1 を除いて UT 検查にお いて不合格となった試験体群は変形能力の低下が認められるが、 FbllのようにUT 検查が合格判定であるにもかかわらず、変形能力 の低下が著しいものもある。前述の破面観察結果からわかるように Fbll は板幅方向よりも板厚方向に欠宿寸法が大きく、UT 検查では 板厚方向の欠陷寸法を検出することが困難であるためと考えられる。 5.结誝

欠陥を有する柱梁溶接接合部の実大実験を行い、溶接欠陷が変形能 カに与える影響について検討した。本研究から得られた主な知見を 以下に示す。

1）溶接欠陷の大きさや分布状況などが異なる場合でも、WES2805

による等価な龟裂に㯰き換える亀裂特性寸法は、柱梁溶接部の変

形能力を評価する上で有効な指標となりうる。

2) 溶接欠陥が柱梁接合部の变形能力に与える影響は大きく、本来そ の部材が持つ保有性能を大きく低下させる。特に等価亀裂長さ で $10 \mathrm{~mm}$ を越えると変形能力が低下する。

本研究は $0^{\circ} \mathrm{C}$ 吸収エネルギーがダイアフラムで約 $90 \mathrm{~J} 、 \mathrm{HAZ-ボ}$ ンド部で約 $130 \mathrm{~J}$ と比較的良好な鞋性の鋼材を用いた結果であり、 鋼材や HAZ-ボンド部が低勒性の場合に溶接欠陷が柱梁溶接接合部 の変形能力に与える影慗について、今後検討する必要がある。

\begin{tabular}{|c|c|c|c|c|c|c|c|c|}
\hline \multirow{2}{*}{ 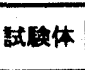 } & \multicolumn{4}{|c|}{ 超音波探倠槙㿽結果 } & \multicolumn{4}{|c|}{ 破面篗寞轺果 } \\
\hline & $X(\mathrm{~mm})$ & $\mathrm{L}(\mathbf{m m})$ & 領域 & 合否 & ld(mm) & hd(mm) & $\mathbf{s} \alpha$ & $A(\mathrm{~mm})$ \\
\hline $\mathrm{FaS1}$ & $0 \sim 9$ & 9 & III & 0 & 12 & 4 & 0.01 & 6.4 \\
\hline $\mathrm{FaMl}$ & $0 \sim 9$ & 9 & II & 0 & 23 & 12 & 0.04 & 16.5 \\
\hline FaM2 & $0 \sim 41$ & 41 & III & $x$ & 25 & 14 & 0.05 & 18.7 \\
\hline FaM3 & $10 \sim 15$ & 5 & II & 0 & 20 & 9 & 0.03 & 13.1 \\
\hline FaLl & $0 \sim 42$ & 42 & IV & $x$ & 51 & 13 & 0.11 & 22.9 \\
\hline FbM1 & $10 \sim 20$ & 10 & II & 0 & 二 & $=$ & - & - \\
\hline FbM2 & $20 \sim 30$ & 10 & III & $\mathrm{O}$ & $=$ & - & $=$ & $=$ \\
\hline Fbml & $10 \sim 15$ & 5 & II & 0 & - & $=$ & - & - \\
\hline FbL1 & $8 \sim 35$ & 27 & III & $x$ & 44 & 6 & 0.03 & 11.4 \\
\hline Fbl1 & $0 \sim 10$ & 10 & III & $\mathrm{O}$ & 18 & 19 & 0.07 & 18.0 \\
\hline FbLL1 & $0 \sim 40$ & 40 & V & $x$ & 44 & 12 & 0.10 & 23.4 \\
\hline
\end{tabular}

$\mathrm{s} \alpha$ : 欠脽断面事 A : 烈特性寸法

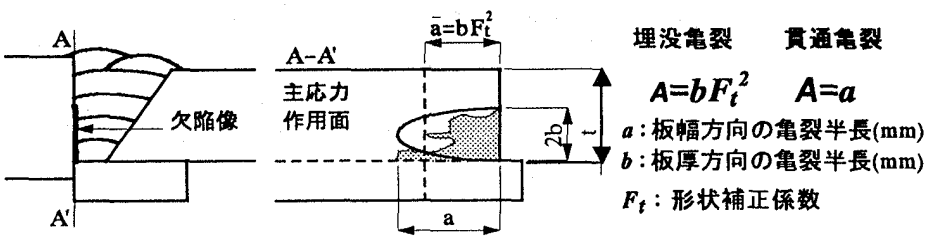

图 14 亀裂特性寸法の標準化方法と算出方法

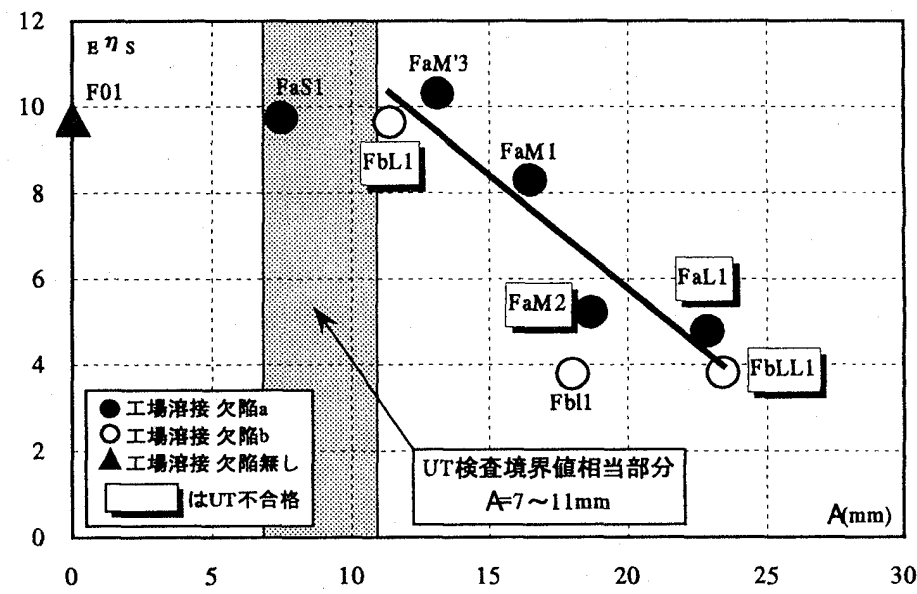

图 15 龟裂特性寸法(破面钼察結果)と装形能力の関係

参考文献

1）加藤 勉・森田耕次・古沢平夫 : 超音波斜角探稘法による溶接欠陥の評価 （I）、日本建築学会論文報告集、第 241 号、昭和 51 年 3 月、pp. 33 41 2）加藤 勉・森田耕次・古沢平夫：超音波斜角探傷法による溶接欠宿の評価 (II)、日本建築学会論文報告集、第 244 号、昭和 51 年 6 月、pp. 21 31 3）日本建築学会 : 銅構造建筑溶接部の超音波探傷検查基準・同解説 1996 年 10 月

4）藤本盛久・泉 満：猖を有する溶接部の変形能力に関する研究（その1 T 継手突合せ溶接部の低サイクル塑性疲労実験)、日本建築学会論文報告集、 第 288 号、昭和 55 年 2 月、pp. $61 \sim 71$

5）藤本盛久・泉満：欠陷を有する溶接部の変形能力に関する研究（その $2 \mathrm{~T}$ 継手突合せ溶接部の低サイクル腤性疲労実験)、日本建築学会論文報告集、 第 303 号、眧和 56 年 5 月、pp. 21 30

6）藤本盛久・中込忠男・泉 満：欠楩を有する溶接部の変形能力に関する研 究（その 3 単純引張試験における欠陷寸法および板厚の影暨と非線形破 壊力学的考察)、日本建築学会論文報告集、第 328 号、昭和 58 年 6 月、pp. $71 \sim 81$

7）鈴木孝彦・石井 匠・森田耕次・高梨晃一：欠陥を有する杜梁溶接接合部 の破墑性状に関する実験的研究、鋸構造論文集、第 6 巻、第 23 号、1999 年 9 月、pp. $149 \sim 164$

8）日本溶接協会:WES2805 溶接継手の脆性破壊発生及び疲労き裂進展に対す る欠楩の評価方法 1997

（2001年10月10日原稿受理，2002年 2 月21日採用決定） 